\title{
Creating Benefits from 0mega-3 Functional Foods and Nutraceuticals
}

\author{
Catharine Clark ${ }^{1}$, Bill Lands ${ }^{2}$ \\ ${ }^{1}$ Clark Consulting and Coaching, Frederick, USA \\ ${ }^{2}$ American Society for Nutrition, College Park, USA \\ Email: Catharine@ClarkConsultingandCoaching.com
}

Received 26 October 2015; accepted 20 December 2015; published 23 December 2015

Copyright (C) 2015 by authors and Scientific Research Publishing Inc.

This work is licensed under the Creative Commons Attribution International License (CC BY). http://creativecommons.org/licenses/by/4.0/

(c) ()

\section{Abstract}

Foods currently eaten by Americans have abundant amounts of essential omega-6 (n-6) nutrients and relatively few omega-3 (n-3) nutrients. The average omega 3 - 6 balance score of typical US foods is about -6 . This imbalance causes the average American to accumulate tissue proportions of n-3 and n-6 highly unsaturated fatty acids (HUFA) with about 77\% n-6 in HUFA. This HUFA balance links to many chronic health conditions that are made worse by overabundant actions of food-based omega-6 HUFA. Americans currently spend more on treating food-based health conditions than they spend on food. Less medication is needed to treat signs and symptoms when a key dietary cause of the signs and symptoms is prevented. Informed food producers can readily prepare and market new food products with more n-3 and less n-6 nutrients to reverse the current national nutrient imbalance and help people attain and maintain a healthy HUFA balance. New functional foods and nutraceuticals will help consumers shift their financial resources from treating signs and symptoms caused by HUFA imbalance to preventing the nutrient imbalance that causes the need to treat.

\section{Keywords}

Eicosanoids, Highly Unsaturated Fatty Acids (HUFA), Inflammation, Omega-3 (n-3) Fatty Acid, Omega-6 (n-6) Fatty Acid

\section{Introduction}

Essential fatty acids (EFA) are vitamin-like nutrients needed for healthy human physiology. The 18-carbon polyunsaturated omega-3 (n-3) $\alpha$-linolenic acid and omega-6 (n-6) linoleic acid are abundant in foliage and leafy vegetables, such as spinach, broccoli and cauliflower. When eaten, the n-3 nutrients compete with n-6 nutrients 
for metabolism to longer more highly unsaturated fatty acids (HUFA) which accumulate in the phospholipids of tissue membranes. A competitive hyperbolic equation [1] describes the diet-tissue relationship by which the EFA in foods maintain proportions of n-3 and n-6 HUFA in human tissues. The current average EFA intakes in US foods have an omega 3 - 6 balance score near-6, whereas traditional Mediterranean foods averaged near -3 and traditional Japanese foods averaged near +2 [2]. These average scores maintain tissue HUFA balances near $75 \%, 60 \%$, and $40 \%$ n-6 in HUFA, respectively. Measurements obtained from apparently healthy people with different traditional food habits range from $25 \%$ to $85 \%$ n-6 in HUFA. The \%n-6 in HUFA is an objective measure of n-3 and n-6 nutrient intakes [2].

The HUFA balance predictably linked to average EFA intakes is also associated with a risk for chronic inflammatory disorders [3]. People with more than 50\% n-6 in HUFA have a greater risk of death from cardiovascular disease (CVD) than people with less than 50\% n-6 in HUFA. Mechanisms for the CVD pathophysiology include conversion of the n-6 HUFA, arachidonic acid, into powerful inflammatory hormone-like eicosanoids that amplify events in vascular inflammatory atherosclerosis and fatal thrombosis [4] [5]. In the absence of dietary n-3 nutrients, intakes of n- 6 linoleic acid as low as 0.4 percent of food energy ( 0.4 en\%) can give $50 \%$ n-6 in HUFA. Eating less may lead to EFA deficiency, and eating more may increase the risk for excessive n- 6 HUFA actions. Thus, dietary n-6 linoleate has a very narrow therapeutic window [4]. An important action of dietary n-3 nutrients is to raise the proportion of n-3 in tissue HUFA and to widen the range of n-6 intake that has a low risk of excessive $n-6$ HUFA action.

Plant foods common in tropical Africa during early human evolution likely had omega 3 - 6 balance scores near 0 , like leafy foliage (0), cassava $(-0.1)$, sweet potato $(-0.5)$, yam $(-0.4)$, plantain $(-0.1)$ and taro $(-3)$ [6]. Over time, people in central and western Africa selectively acquired a genetic haplotype which has faster $\Delta 6$ and $\Delta 5$ desaturation activity [7]. That gave faster conversion of dietary n-3 and n-6 PUFA to tissue HUFA and ensured supplies of n-3 and n-6 HUFA adequate for human brain and retinal function during rapid infant development. However, it now makes many African-Americans more responsive than Caucasians or Asians to the very high amounts of n-6 linoleate from food oils in the current American diet (7 en\%, rather than the 0.4 en\% that prevents EFA deficiency). The consequence is a greater tendency for a higher $\% \mathrm{n}-6$ in HUFA and for more unwanted chronic inflammatory disorders. African-Americans have higher prevalence of chronic disease including: cardiovascular disease, hypertension, colorectal cancer, obesity, asthma, and periodontitis [8]. In fact, the prevalence of type 2 diabetes (insulin resistance) is nearly twice as high among African-American adults compared to white adults [8].

\section{Multiple Chronic Conditions Are Becoming Financially Unsustainable}

The general status of health and wellness (or its counterpart, sickness and death) can be described in many ways. For example, the US economy currently allocates more financial resources to healthcare than to food, and foodbased imbalances cause the high need for healthcare [9]. The Centers for Disease Control and Prevention (CDC) estimated that chronic health conditions — such as heart disease, stroke, cancer, diabetes, obesity, and arthritis-are among the most common, costly, and preventable of all health problems [10]. Eighty six percent (86\%) of healthcare spending is for chronic medical conditions [10] [11]. The US will likely spend $\$ 2.7$ trillion treating chronic diseases in 2015 (Table 1) - much of which is considered preventable. This is more than total healthcare spending in 2010. The US needs to change its foods.

The US healthcare system is focused on discovering treatments rather than preventing chronic disease [16]. While medications are profitable (and sometimes a useful interim step), they can have undesired side effects,

Table 1. Cost of chronic health conditions.

\begin{tabular}{lcccccc}
\hline Year & $\begin{array}{c}\text { Healthcare } \\
\text { Spending(\$) }\end{array}$ & \% of GDP & $\begin{array}{c}\text { Healthcare } \\
\text { (Avg \$/person) }\end{array}$ & $\begin{array}{c}\text { Chronic Disease } \\
\text { Prevalence }\end{array}$ & $\begin{array}{c}\text { Chronic Disease } \\
\text { Spending (\$) }\end{array}$ & $\begin{array}{c}\text { Chronic Disease } \\
\text { (Avg \$/person) }\end{array}$ \\
\hline 2000 & $1.4 \mathrm{~T} \mathrm{[12]}$ & $13.8[14]$ & $4,878[14]$ & $70 \%[15]$ & $1.0 \mathrm{~T}$ & 3,415 \\
2005 & $2.0 \mathrm{~T} \mathrm{[12]}$ & $16.1[14]$ & $6,868[14]$ & $75 \%[16]$ & $1.5 \mathrm{~T}$ & 5,151 \\
2010 & $2.6 \mathrm{~T} \mathrm{[12]}$ & $17.9[14]$ & $8,402[14]$ & $86 \%[11]$ & $2.2 \mathrm{~T}$ & 7,226 \\
2015 & 3.1T [13] & $18.0[13]$ & $10,125[13]$ & $86 \%[11]$ & $2.7 \mathrm{~T}$ & 8,708 \\
\hline
\end{tabular}


and their continued use is needed when the food-based cause remains unaddressed. Translating knowledge of risk factor mechanisms into effective informed preventive nutrition actions is an important step toward preventing costly, chronic conditions resulting from food-based mediators [9].

Heart disease, obesity, and type-2 diabetes are at epidemic levels in the US, and they have well-documented food-based n-6 mediators [4] [5]. Depression is another epidemic condition not yet recognized by the public to associate with HUFA balance [17]. Chronic disease and depression are mutually reinforcing: chronic disease can exacerbate depression, while depression can lead to chronic disease [16]. Pharmaceutical companies know imbalanced actions of n-6 mediators for which they produce and market many medications to mitigate food-based pathophysiology. Food producers and manufacturers are becoming aware of their opportunity to significantly alter food-based pathophysiology. Their actions in making better-balanced foods available can shift current health conditions toward increased wellness for the public.

Understanding the causal links between foods and food-based health conditions allows deliberate, explicit implementation of effective preventive nutrition programs [9]. When people increase their intake of n-3 nutrients while decreasing excess n-6 nutrients, they lower the health risk assessment (HRA) biomarker, the \%n- 6 in HUFA. Effective preventive nutrition addressing the root causes of chronic diseases can benefit the US economy. In 2015, the US will spend $86 \%$ of its $\$ 3.1$ trillion healthcare resources treating chronic diseases. Among the most prevalent chronic conditions, allergies rank \#3 and asthma ranks \#8 for adults, whereas for children, asthma and allergies rank \#1 and \#2, respectively [11]. Allergies are a major trigger for asthma. In addition, chronic obstructive lung disease and bronchiectasis are ranked \#11 in prevalence for adults, and chronic obstructive pulmonary disease (COPD) is the third leading cause of death in the US [18]. A common aspect of all these immune-inflammatory disorders is excessive action of n-6 eicosanoids derived from an over-abundant intake of n-6 nutrients.

The eicosanoids are potent signaling molecules, and n-3 and n-6 eicosanoids act at selective receptor sites in nearly every tissue of the human body [5]. The cysteinyl leukotriene eicosanoids are potent bronchoconstrictors formed by 5-lipoxygenase and leukotriene $C$ synthase after phospholipase releases the $n-3$ and n-6 HUFA precursors from tissue membrane phospholipids [19]. Both n-3 and n-6 leukotrienes can increase bronchopulmonary distress in asthma and COPD, however formation of n-6 LTC $_{4}$ is more intense than n-3 LTC 5 [20] [21]. A major contributor to recruiting leukocytes that amplify inflammatory conditions is the vigorous chemotactic response of the BLT1 receptor with n-6 $\mathrm{LTB}_{4}$. It is 100 -fold greater than the response with n-3 LTB 5 [22]. Inflammation is amplified as food-based n- $6 \mathrm{LTB}_{4}$ attracts more leukocytes to an area and signals for release of chemokines (a protein activating additional white blood cells).

Macrophages play a key role in the pathophysiology of obesity-induced insulin resistance. These inflammatory cells accumulate in crown-like structures around adipocytes [23], and become a significant portion (up to $40 \%$ [24]) of the cells in obese adipose tissue. Macrophages release cytokines and $\mathrm{LTB}_{4}$ that recruit more inflammatory cells as adipose tissue develops systemic inflammatory characteristics [23]. LTB $_{4}$ acting through the BLT1 receptor directly induces inflammation and insulin resistance [24]. Genetically altered mice missing the BLT1 receptor were protected from glucose intolerance and insulin resistance [24] [25]. Inhibition of $\mathrm{LTB}_{4}$ could be a future goal for pharmaceutical treatment of insulin-resistance. Conversely, with n-6 LTB 4 actions on BLT1 being 100-fold greater than n-3 LTB $_{5}$ [22], a promising form of primary prevention is reducing dietary n- 6 and increasing the intake of n-3 functional foods. Informed food choices can likely decrease obesity, inflammation, and insulin resistance and have fewer side effects than medications or surgical procedures.

The obesity epidemic in the US has not been resolved by the multi-billion dollar weight-loss industry. Now categorized as a disease, obesity and its associated inflammatory processes play key roles in a complex chain of events linked to n- 6 nutrients. The endocannabinoid system regulates food intake mediated by products of n- 6 linoleic acid (LA) [26] [27]. Elevated endocannabinoids increase weight gain while adipocytes become larger and adipose tissue more inflamed with macrophage infiltration [27] [28]. Balancing weight-promoting n-6 nutrients with n-3 nutrients normalized endocannabinoid tone and body mass. That approach merits careful attention in preventing undesired appetitive behaviors and in maintaining food energy balance.

The large multi-year Look AHEAD clinical trial hypothesized that obesity is a valid surrogate for cardiovascular disease (CVD) [29], the \#1 cause of death in the US for many decades. The trial lowered the average body mass of 5145 overweight or obese participants with intent to reduce non-fatal myocardial infarction, hospitalized angina, and non-fatal stroke [29]. However, following successful weight reduction and increased physical activity, the trial was stopped after nearly 10 years because the hypothesis was not supported [29]. Obesity is an 
associative, predictive risk factor of CVD; it is not a valid surrogate. The health risk assessment factor, \%n-6 in HUFA, has a high correlation with CVD and a causal mechanistic basis [4] [30]. When people examine blood samples from the Look AHEAD participants, they may find an association between \%n-6 in HUFA and CVD mortality and morbidity. This would redirect attention toward a more effective preventive nutrition strategy of lowering n-6 intakes and raising n-3 intakes.

As populations shifted from their traditional dietary patterns toward modern Western food habits, they experienced increased prevalence of deaths from chronic disease. One example is the increased deaths from prostate cancer in Japan and Italy [31]. Japanese historically had seafood as a dietary staple, a low \%n-6 in HUFA as an objective biochemical outcome, and one of the lowest rates of prostate cancer deaths in the world. As the average \%n-6 in HUFA increased from 35\% to 50\%, prostate cancer deaths of elderly Japanese rose from 40 to 400 per 100,000 population. In Italy, where a traditional Mediterranean diet was typical in 1970, deaths from prostate cancer were near 250 per 100,000. However, over the next 30 years, as dietary habits became Westernized, the death rate doubled to 500 [31]. During this period prostate cancer deaths of elderly men in UK, France, and US remained near 500 to 600 per 100,000 . In the US, it is the $5^{\text {th }}$ leading cause of cancer death [32]. In 2015, there will likely be 220,000 new cases and 27,000 prostate cancers deaths in the US, with higher prevalence and deaths among African Americans [32]. Reducing the dietary intake of n- 6 nutrients enables increased n-3 intakes to competitively attenuate actions of the n-6 thromboxane, $\mathrm{TXA}_{2}$, in facilitating cancer growth [33].

There is no shortage of peer-reviewed studies listed by PubMed detailing mechanisms by which the innate immune system is amplified by n- 6 actions. Thousands of these studies specify the eicosanoids involved (e.g., $\mathrm{LTB}_{4}, \mathrm{TXA}_{2}, \mathrm{PGE}_{2}, \mathrm{PGF}_{2 \alpha}, \mathrm{PGI}_{2}$ ). However, there is a shortage of information about which foods cause major imbalances in n-3 and n-6 nutrient intakes. Useful for this purpose are the omega 3-6 balance scores derived from eleven different n-3 and n-6 fatty acids based on information in the USDA Nutrient Database [2]. The scores predict the impact of a food item on the HRA biomarker, \%n-6 in HUFA. Balance scores have dimensions of milligrams per Calorie ( $\mathrm{mg} / \mathrm{kcal}$ ), and the negative and positive values combine together to give a predicted biomedical outcome for the \%n-6 in HUFA. As consumers combine current food items with functional foods that have more positive (less negative) scores, the incremental differences add together, and can significantly shift the \%n-6 in HUFA and clinically relevant outcomes in as little as 3 months [34]. This is important as food producers and marketers begin to resolve the current preventable epidemics.

\section{Address the Cause Not Just the Symptoms}

Many medications relieve signs and symptoms of food-based chronic conditions. For example, low-dose aspirin decreases the actions of excessive n-6 thromboxane, TXA $_{2}$, in blood platelets [5]. However, when the dietary imbalance causing their food-based condition has not been prevented, consumers need continual medication. This fits a profitable business model for pharmaceutical companies and manufacturers of over-the-counter medications. However, some question the benefit of treating signs and symptoms while leaving the food-based imbalance to cause additional harm [3]. Significant increases in chronic disease spending per person are likely to continue in the absence of effective preventive nutrition (Table 1).

Creating functional foods and promoting new food choices is not in business plans of pharmaceutical companies or manufacturers of over the counter drugs. Moreover, if the CDC is correct that the US healthcare system "is not designed to prevent chronic diseases" and "has primarily focused on discovering [new] treatments" [16], then the healthcare system is financially unsustainable and needs redesigning. Re-allocating \$2.7T/year toward preventive nutrition may be sufficient financial incentive to motivate action [9]. Tools and apps are now available [35] to use the known competitive, hyperbolic diet-tissue relationship among EFA [1] and design new functional foods and nutraceuticals for better nutrient balance and health outcomes for consumers. The empirical equation quantitatively describes how lowering n-6 nutrient intake makes n-3 nutrients more effective in creating balanced HRA biomarker values. The concept of Omega Balance [36] addresses the current nutritional cause for many signs and symptoms, and new functional foods with high positive scores will not have adverse side effects seen with current medications. Informed preventive nutrition offers positive outcomes with lower cost.

To examine the benefit of a better HUFA balance, a recent randomized clinical trial on severe chronic headache pain designed two diets quite different from typical American diets in having much lower amounts of n-6 LA [34]. The low-n-6 diet (L6) replaced high-LA foods with low-LA foods. Adding n-3 nutrients to that diet gave a high n-3, low n-6 diet (H3-L6). During the 3-month clinical trial, the L6 diet gave a significant reduction 
of pain in three objective clinical measures as patients' HRA values went from 78\% n-6 in HUFA to 75\%n-6 in HUFA. More importantly, the H3-L6 group changed their average \%n-6 in HUFA from 77\% to $61 \%$ and experienced progressive reduction in pain during 3 months, a $40 \%$ lower need for medications, and an increased quality of life [34] [37].

This clinical trial demonstrated how rapidly an informed selection of foods can change the HUFA balance and its physiological consequences. The authors noted that more improvement in psychological distress may occur if the intervention was longer [37]. Also, individuals with an aversion to seafood were not fully compliant, and use of n-3 supplements may further improve outcomes [38]. Supplemental nutraceutical n-3 is a constructive alternative to improve HRA biomarkers in an open free-living population setting. In all scenarios with added n-3 nutrients, reducing dietary n- 6 intake ensures more positive outcomes on objective and subjective measures of health, and a decreased need for medication in chronic conditions [34] [37].

\section{Creating Functional Foods}

Investigators developing diets to give a better tissue HUFA balance replaced high-LA oils with macadamia-oilvinaigrette salad dressing, and used fat-free mayonnaise [38] [39]. Including fatty seafood rich in n-3 HUFA (e.g. wild salmon, trout, tuna, and sardines) plus functional foods created with flax meal (i.e., ground flax seeds) can provide more n-3 nutrients. Easily arranged recipes for muffins, granola, and bean dip create new functional foods by adding flax meal [38]. In considering a better tissue HUFA balance, the Department of Defense (DoD) noted a substantially increased cognitive load on the warfighter produced a need for better protection and recovery from wounds [40]. However, the current diet for active duty military personnel is imbalanced in n-3 and n-6 nutrients, as it resembles the standard American diet [2] [40] [41]. Assessment of 287 active-duty soldiers showed an average $81 \%$ n-6 in HUFA [42]. The DoD concluded that restoring omega-3 fatty acids to optimal levels may improve performance and restore impaired personnel to healthy fit status. To sustain US leadership, DoD established goals for 2030 as shown in Figure 1 [40].

Sample garrison foods were analyzed using the empirical equation noted in the Introduction [1]. They predicted an average value of 78\% n-6 in HUFA [41]. Substituting n-3 rich foods, increasing low n-6 variants, and replacing high-LA with low-LA oils resulted in a substantial observed change in the \%n-6 in HUFA, thus shifting

TECHNOLOGY AND INNOVATION ENABLERS FOR SUPERIORITY 2030

KEY INVESTMENT OPPORTUNITIES TO ACHIEVE SUPERIORITY THROUGH ENHANCING FORCE EFFECTIVENESS

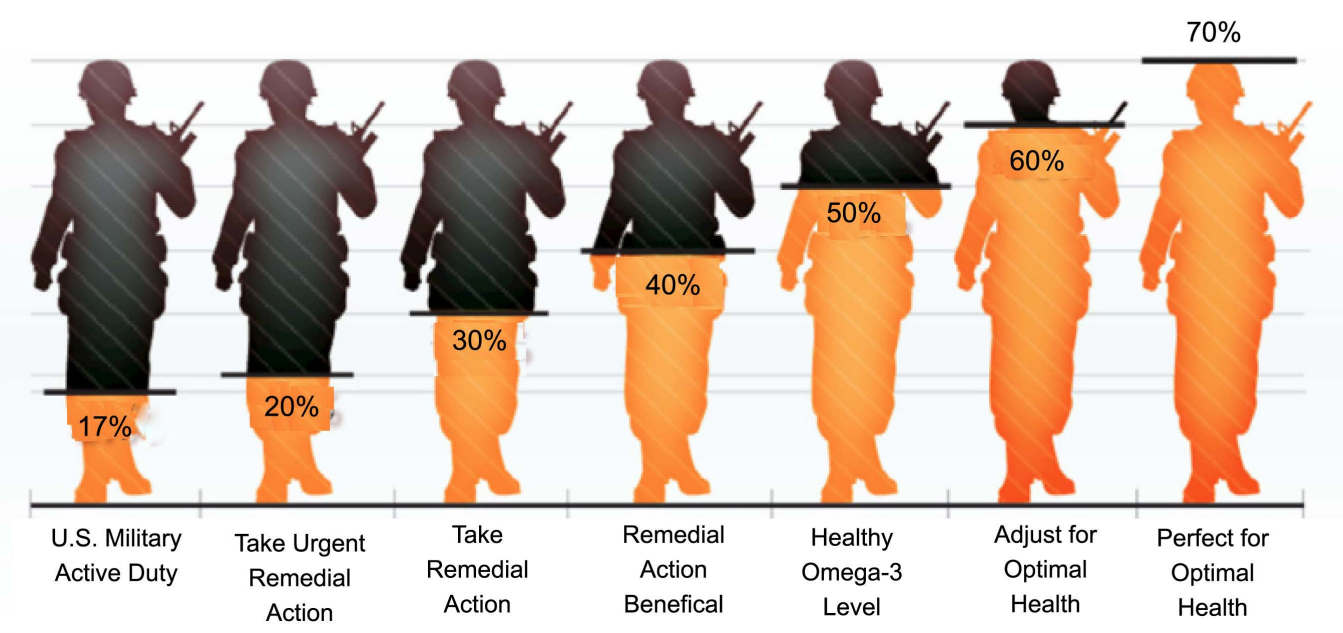

Figure 1. Balance of n-3 in HUFA related to optimal health and force effectiveness. Omega Balance is expressed as \%n-3 in HUFA. U.S. Military Active Duty is shown as 17\% n-3 in HUFA (i.e., 83\% n-6 in HUFA) and optimal health is considered $60 \%$ - 70\% n-3 in HUFA. Reprinted from Defense Science Board ([40], p. 57). 
dietary patterns of active duty warfighters away from traditional nutrition guidelines [41] and current public advice from the Food and Nutrition Board [4]. The DoD implemented their decision by engaging food producers to assemble functional foods for garrison menus. Results presented in March 2015 during a public lecture showcased functional foods that DoD cooperatively developed with several food companies: Vital Choice, Smartfish, Omega Foods, DuPont, Belovo, and Aidells Sausage Company. New food items included salad dressings using low n-6 soybean oil [43] plus n-3 enriched chicken, eggs and fruit beverages. Researchers noted that lowering dietary n-6 in combination with elevating n-3 acts more potently to lower tissue n- 6 HUFA balance than either approach alone [41]. Food producers play a positive role in helping the DoD move toward its goal of resilient warfighters with $40 \%-50 \%$ n-6 in HUFA. There is much more they can do to expand markets to the broader public.

The Department of Agriculture (USDA) supported development of new peanut cultivars that can be useful as functional foods. Researchers in Florida, Georgia, North Carolina, Oklahoma, Texas and the UK [44]-[47] described new varieties that can replace staples in the American diet. Currently, peanuts, peanut butter, and peanut oil contain large amounts of n-6 have omega 3 - 6 balance scores of $-26,-24$, and -36 , respectively [35]. Variants with less n-6 and much more monounsaturated oleic acid can be effective functional foods. In addition to having improved Omega Balance scores, low-linoleate products have greater shelf life. For many years the fats and oils industry handled low n-6 food oils from coconut or macadamia or from selected cultivars of sunflower, soybean, safflower, and canola which are not yet widely marketed to the public. These oils can be excellent starting points for developing new functional foods to improve the HUFA balance in consumers.

Many nutrition advisors recommend using foods rather than supplements to achieve dietary goals, yet few give consumers explicit data on the amounts of n-3 and n-6 nutrients in foods. Individuals can find information on how to create their own balance of n-3 and n-6 nutrients by downloading the Omega Meals tool onto their personal computer [35]. A simple example is converting snack pretzels (1 ounce (oz), $103 \mathrm{kcal}$, score $=-2.1$ ) into a functional food by combining it with flax oil ( 3 teaspoons (tsp), $120 \mathrm{kcal}$, score $=+46$ ). The Omega Meals tool combines the data and shows the resulting $223 \mathrm{kcal}$ snack has an omega $3-6$ balance score of +24.2 which has a very good impact on a person's HRA biomarker, \%n-6 in HUFA [35]. To prepare this snack: break up the pretzels in a small bowl, drizzle the flax oil, and stir to coat. This snack is an alternative to a $1.25 \mathrm{oz}$ serving of tree nuts which provide 206 - $231 \mathrm{kcal}$ and much more negative balance scores (Table 2). Another functional food combines $4 \mathrm{oz}$ low-fat cottage cheese $(81 \mathrm{kcal}$, score $=-0.2)$ with 1 tsp flax oil ( $40 \mathrm{kcal}$, score $=+46)$ to give a $121 \mathrm{kcal}$ snack (score $=+15$ ). Recipes and meal plans made with Omega Meals can be saved for future

Table 2. Balance of n-3 and n-6 fats in tree nuts. The milligrams of n-3 and n-6 essential polyunsaturated acids (PUFA) per ounce of tree nuts. The color code for Balance Scores reflects the likely impact food items will have on the HRA value, \% n- 6 in HUFA.

\begin{tabular}{|c|c|c|c|c|}
\hline $\begin{array}{l}\text { Tree Nuts } \\
\quad(1 \mathrm{oz})\end{array}$ & $\begin{array}{c}\text { PUFA } \\
\text { n-3 }\end{array}$ & $\begin{array}{c}\text { PUFA } \\
\text { n-6 }\end{array}$ & BALANCE SCORE & \\
\hline Walnuts & 2574 & 10,799 & -44 & \\
\hline Brazil nuts & 15 & 6769 & -40 & \\
\hline Peanuts & 3 & 4675 & -28 & \\
\hline Pecans & 280 & 5848 & -28 & very good effect \\
\hline Pistachio & 73 & 3823 & -23 & $\begin{array}{l}\text { good effect } \\
\text { OK effect }\end{array}$ \\
\hline Almonds & 1 & 3494 & -21 & $\begin{array}{l}\text { not very good effect } \\
\text { bad effect }\end{array}$ \\
\hline Cashew nuts & 18 & 2206 & -14 & awful effect \\
\hline Hazelnuts & 25 & 2221 & -12 & \\
\hline Chestnuts & 15 & 125 & -3 & \\
\hline Macadamia & 58 & 367 & -1.5 & \\
\hline
\end{tabular}


use, modified as desired, and printed to share with friends. Every recipe and meal plan displays a chart indicating the likely impact on the predictive HRA biomedical value, the \%n-6 in HUFA [35].

The top 100 Key Foods for Americans [48] have an average Omega Balance Score near -6 [2], related to a HRA value of $78 \%$ n- 6 in HUFA (like common American diets). Removing ten foods with the most negative scores leaves 90 Key Foods with an average Score of -3 and an HRA value of 63\% n-6 in HUFA (like traditional Mediterranean diets). Possible alternatives to the removed items are in Table 3.

The top 100 foods do not include seafood which has positive Balance Scores: scallops, +15 ; shrimp, +29; crab, +30; flounder, +30; mussels, +32; white tuna, +46; sea bass, +49 ; sardines, +53 ; striped bass, +55 ; Coho salmon, +57; Eastern oysters, +57; kippered herring, +70; and canned pink salmon, +83. Also, marine plants are becoming more available to US consumers: kelp, -2 ; laver, +14 ; and wakame, +26 . The American Heart Association and the American Psychiatric Association recommend eating seafood twice a week. Consumers need help in finding more functional foods with positive scores that lower their \%n-6 in HUFA [36], improve health and quality of life [34] and shift personal finances from treatments to other desired uses [9].

Figure 2 illustrates an Omega Meals plan that initially had an overall Balance Score of -6.9 with an estimated HRA value of $82 \%$ n- 6 in HUFA (near typical American values of -6 to -7 and $75 \%-80 \%$, respectively). It was altered by replacing turkey $(-15.9)$ with salmon $(+52.6)$ to give an overall Score of +2.3 and a predicted HRA value of 37\% n-6 in HUFA (near traditional Japanese levels). This plan can be changed further by replacing walnuts $(-44.4)$ with the pretzel/flax oil snack described above $(+24)$; olive oil $(-8.3)$ with coconut oil $(-2.1)$; and avocado $(-10.4)$ with a glass of wine $(0)$. The overall Balance Score would then be +9.5 with an estimated HRA biochemical outcome of 19\% n-6 in HUFA (near traditional Greenland Inuit levels). Existing food items already allow people to make food choices that lower their HUFA balance, and new functional foods and nutraceuticals certainly will make that task much easier. Such new consumer items can positively shift US financial outlays from healthcare treatments to economic development [9].

Table 3. Possible Alternatives for Widely Consumed US Foods. Ten foods from the top 100 Key Food for Americans [48] are shown with their corresponding Balance Scores and possible alternatives. All Scores are based on milligrams of n-3 and n-6 essential polyunsaturated acids (PUFA) per Calorie.

\begin{tabular}{|c|c|c|c|}
\hline $\begin{array}{l}\text { Food with a Very } \\
\text { Negative Score }\end{array}$ & $\begin{array}{l}\text { Balance Score } \\
\text { (per kcal) }\end{array}$ & Possible Alternatives & $\begin{array}{l}\text { Balance Score } \\
\text { (per kcal) }\end{array}$ \\
\hline \multirow{3}{*}{ Soybean oil } & \multirow{3}{*}{-50} & Olive oil & -8 \\
\hline & & Canola oil & -12 \\
\hline & & High-oleic sunflower oil & -4 \\
\hline \multirow{2}{*}{ Mayonnaise } & \multirow{2}{*}{-46} & Fat free mayonnaise & 0 \\
\hline & & Mayonnaise with canola or olive oil & -10 \\
\hline \multirow{2}{*}{ Tub margarine } & \multirow{2}{*}{-39} & Butter & -1 \\
\hline & & Coconut oil & -2 \\
\hline \multirow[t]{2}{*}{ Microwave popcorn } & \multirow[t]{2}{*}{-37} & Low-fat microwave popcorn & -7 \\
\hline & & Fat free “Italian” & 0 \\
\hline \multirow[t]{2}{*}{ “Italian” dressing } & \multirow[t]{2}{*}{-35} & Lemon and olive oil & -8 \\
\hline & & Flax \& olive oil vinaigrette & +19 \\
\hline \multirow{2}{*}{ Potato chips } & \multirow{2}{*}{-29} & Baked potato chips & -8 \\
\hline & & Pretzels with flax oil & +24 \\
\hline Stick margarine & -28 & Butter & -1 \\
\hline \multirow{2}{*}{ Vegetable shortening } & \multirow{2}{*}{-28} & Lard & -10 \\
\hline & & Coconut oil & -2 \\
\hline \multirow{3}{*}{ Peanut butter } & \multirow{3}{*}{-24} & High oleic peanut butter & -4 \\
\hline & & Flax-peanut butter & +4 \\
\hline & & Gouda Cheese & +0.4 \\
\hline \multirow{2}{*}{ Tortilla chip snacks } & \multirow{2}{*}{-22} & Taco-flavor tortillas & -6 \\
\hline & & Flour tortillas & -5 \\
\hline
\end{tabular}




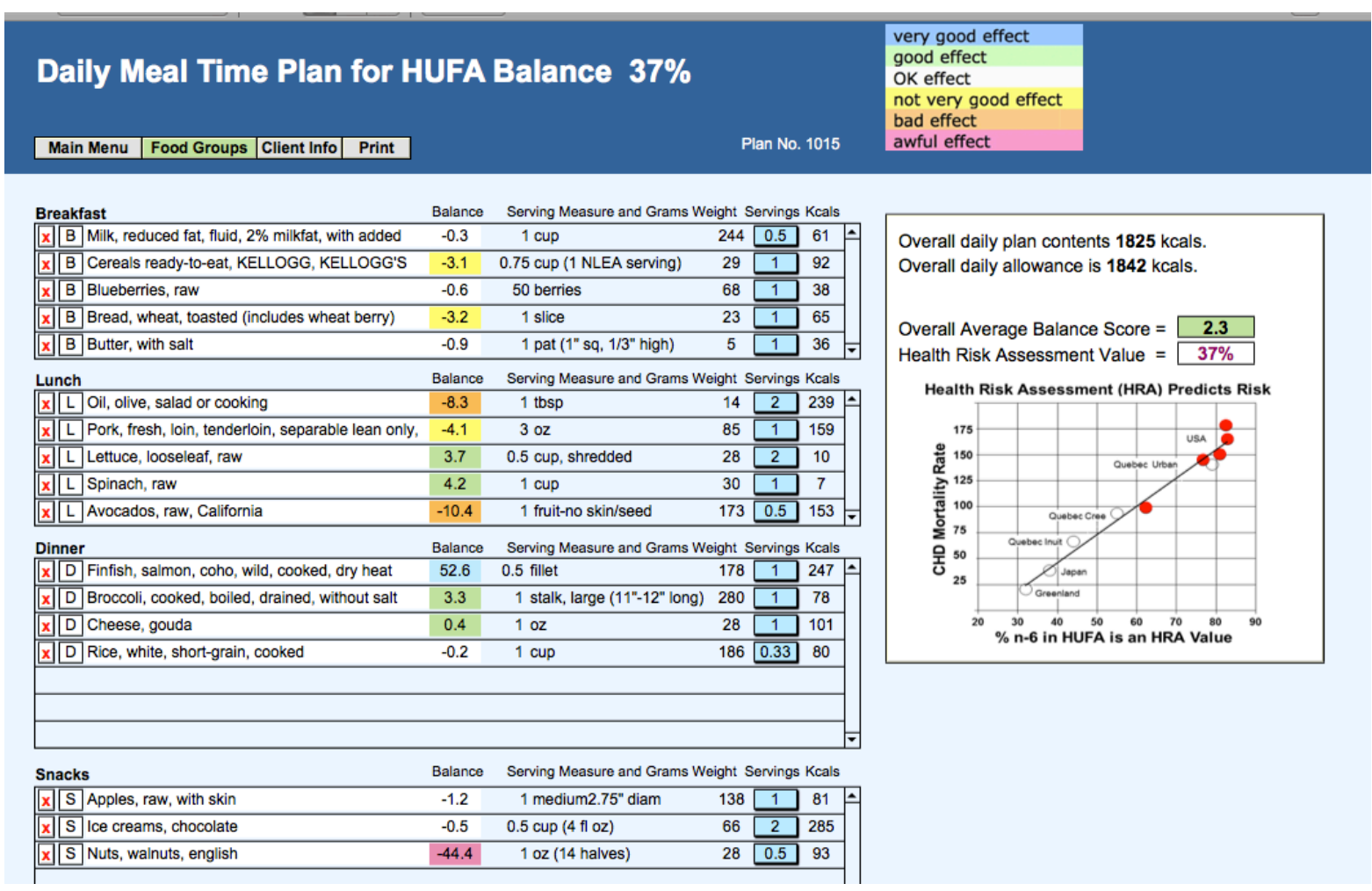

Figure 2. Daily Meal Plan with a Balance Score of +2.3. The meal plan using the Omega Meals tool [35] shows foods eaten at different mealtimes. Highlighting scores by color visually indicates the impact of each food item on the biomedical HRA value, \%n-6 in HUFA.

\section{Conclusion}

A quantitative empirical relationship describes how dietary n-3 and n-6 essential fatty acids maintain the proportions of n-3 and n-6 in tissue HUFA. Traditional food habits of different populations maintain HUFA balances that range from $25 \%$ to $85 \%$ n-6 in HUFA and associate with the incidence and severity of many different chronic disorders made worse by n- 6 eicosanoids. The combined impact of multiple food choices creates HUFA imbalances in Americans. New food choices with more positive omega 3 - 6 balance scores can reverse imbalances. Consumers need new functional foods and nutraceuticals to help them avoid the need to medicate preventable health conditions and to maintain better a quality of life. Tools and apps for making explicit food choices allow individual consumers to arrange balanced food combinations in their homes. In addition, the tools guide food producers and marketers to make balanced combinations available to the many consumers who do not have time to prepare foods at home. The US spends more on treatment of food-based chronic conditions than it does on food. Prevention costs less than treatment. Informed actions using more functional foods and nutraceuticals can shift some of the \$2.7T the US spends annually treating chronic conditions toward preventing the need to treat.

\section{Acknowledgements}

Dr. N. Schoene gave helpful advice on this manuscript.

\section{Author Contributions}

Both authors shared in the preparation of the manuscript.

\section{Conflicts of Interest}

The authors declare no financial arrangements related to this manuscript. CC is a clinical nutrition consultant and $\mathrm{BL}$ is a retired professor of biochemistry. 


\section{References}

[1] EFAeducation.org (2015) Relating Diets to Tissue HUFA. http://efaeducation.org/?p=188

[2] Lands, B. and Lamoreaux, E. (2012) Using 3-6 Differences in Essential Fatty Acids Rather than 3/6 Ratios Gives Useful Food Balance Scores. Nutrition \& Metabolism, 9, No. 46.

http://www.ncbi.nlm.nih.gov/pmc/articles/PMC3533819/pdf/1743-7075-9-46.pdf http://dx.doi.org/10.1186/1743-7075-9-46

[3] Lands, B. (2011) Prevent the Cause, Not Just the Symptoms. Prostaglandins \& Other Lipid Mediators, 96, 90-93. http://dx.doi.org/10.1016/j.prostaglandins.2011.07.003

[4] Lands, B. (2014) Historical Perspectives on the Impact of n-3 and n-6 Nutrients on Health. Progress in Lipid Research, 55, 17-29. http://www.sciencedirect.com/science/article/pii/S0163782714000253 http://dx.doi.org/10.1016/j.plipres.2014.04.002

[5] Lands, B. (2015) Omega-3 PUFAs Lower the Propensity for Arachidonic Acid Cascade Overreactions. Biomed Research International, 2015, Article ID 285135. http://www.hindawi.com/journals/bmri/2015/285135/ http://dx.doi.org/10.1155/2015/285135

[6] Lands, B. (2016) Fatty Acids: Essential Fatty Acids. In: Caballero, B., Finglas, P. and Toldrá, F., Eds., The Encyclopedia of Food and Health, Academic Press, Oxford, Vol. 2, 615-622. http://dx.doi.org/10.1016/b978-0-12-384947-2.00279-8

[7] Ameur, A., Enroth, S., Johansson, A., Zaboli, G., Igl, W., Johansson, A.C.V., Rivas, M.A., Daly, M.J., Schmitz, G., Hicks, A.A., Meitinger, T., Feuk, L., van Duijn, C., Oostra, B., Pramstaller, P.P., Rudan, I., Wright, A.F., Wilson, J.F., Campbell, H. and Gyllensten, A. (2012) Genetic Adaptation of Fatty-Acid Metabolism: A Human-Specific Haplotype Increasing the Biosynthesis of Long-Chain Omega-3 and Omega-6 Fatty Acids. The American Journal of Human Genetics, 90, 809-820. http://dx.doi.org/10.1016/j.ajhg.2012.03.014

[8] Centers for Disease Control and Prevention (CDC) (2015) Minority Health. http://www.cdc.gov/minorityhealth/populations/REMP/black.html

[9] Clark, C. and Lands, B. (2016) What Financial Motivations Support Preventive Nutrition? Nutrition and Health, Unpublished.

[10] Centers for Disease Control and Prevention (2015) Chronic Disease Overview. http://www.cdc.gov/chronicdisease/overview/

[11] Gerteis, J., Izrael, D., Deitz, D., LeRoy, L., Ricciardi, R., Miller, T. and Basu, J., Agency for Healthcare Research and Quality (AHRQ) (2014) Multiple Chronic Conditions Chartbook.

http://www.ahrq.gov/sites/default/files/wysiwyg/professionals/prevention-chronic-care/decision/mcc/mccchartbook.pdf

[12] Health Spending Explorer (2015) Peterson-Kaiser Health System Tracker. http://www.healthsystemtracker.org/interactive/health-spending-explorer/?display=U.S.\%2520\%2524\%2520Billions\& service=Hospitals\%252CPhysicians\%2520\%2526\%2520Clinics\%252CPrescription\%2520Drug

[13] Keehan, S.P., Cuckler, G.A., Sisko, A.M., Madison, A.J., Smith, S.D., Stone, D.A., Poisal, J.A., Wolfe, C.J. and Lizonitz, J.M. (2015) National Health Expenditure Projections, 2014-24: Spending Growth Faster than Recent Trends. Health Affairs, 8, 1707-1717. (Exhibit 3)

[14] Kaiser Family Foundation (2012) Health Care Costs: A Primer. (Figure 1) http://kff.org/report-section/health-care-costs-a-primer-2012-report/

[15] Fries, J.F., Koop, C.E., Sokolov, J., Beadle, C.E. and Wright, D. (1998) Beyond Health Promotion: Reducing Need and Demand for Medical Care. Health Affairs, 17, 70-84. http://dx.doi.org/10.1377/hlthaff.17.2.70

[16] Centers for Disease Control and Prevention (CDC) (2009) The Power of Prevention Chronic Disease . . . the Public Health Challenge of the 21st Century. http://www.cdc.gov/chronicdisease/pdf/2009-Power-of-Prevention.pdf

[17] Hibbeln, J.R. and Davis, J.M. (2009) Considerations Regarding Neuropsychiatric Nutritional Requirements for Intakes of Mmega-3 Highly Unsaturated Fatty Acids. Prostaglandins, Leukotrienes and Essential Fatty Acids, 81, 179-186. http://dx.doi.org/10.1016/j.plefa.2009.06.005

[18] Centers for Disease Control and Prevention (CDC) (2015) Chronic Obstructive Pulmonary Disease. http://www.cdc.gov/copd/index.html

[19] Lands, B. (2016) Omega-3 Fatty Acids Counterbalance Actions of Omega-6 Fatty Acids. In: Raatz, S. and Bibus, D., Eds., Fish and Fish Oils in Health and Disease, Elsevier, Philadelphia

[20] Murphy, R.C., Pickett, W.C., Culp, B.R and Lands, W.E.M. (1981) Tetraene and Pentaene Leukotrienes: Selective Production from Murine Mastocytoma Cells after Dietary Manipulation. Prostaglandins, 22, 613-622.

http://dx.doi.org/10.1016/0090-6980(81)90070-8 
[21] Soderstrom, M., Mannervik, B., Garkov, V. and Hammarstrom, S. (1992) On the Nature of Leukotriene C4 Synthase in Human Platelets. Archives of Biochemistry and Biophysics, 294, 70-74. http://dx.doi.org/10.1016/0003-9861(92)90138-M

[22] Lee, T.H., Sethi, T., Crea, A.E.G., Peters, W., Arm, J.P., Horton, C.E., Walport, M.J. and Spur, B.W. (1988) Characterization of Leukotriene B3: Comparison of its Biological Activities with Leukotriene B4 and Leukotriene B5 in Complement Receptor Enhancement, Lysozyme Release and Chemotaxis of Human Neutrophils. Clinical Science, 74, $467-$ 475. http://dx.doi.org/10.1042/cs0740467

[23] Mohanan, S., Horibata, S., McElwee, J.L., Dannenberg, A.J. and Coonrod, S.A. (2013) Identification of Macrophage Extracellular Trap-like Structures in Mammary Gland Adipose Tissue: a Preliminary Study. Frontiers in Immunology, 4, 1-8. http://www.ncbi.nlm.nih.gov/pmc/articles/PMC3600535/ http://dx.doi.org/10.3389/fimmu.2013.00067

[24] Li, P., Oh, D.Y., Bandyopadhyay, G., Lagakos, W.S., Talukdar, S., Osborn, O., Johnson, A., Chung, H., Mayoral, R., Maris, M., Ofrecio, J.M., Taguchi, S., Lu, M. and Olefsky, J.M. (2015) LTB4 Promotes Insulin Resistance in Obese Mice by Acting on Macrophages, Hepatocytes and Myocytes. Nature Medicine, 21, 239-247. http://dx.doi.org/10.1038/nm.3800

[25] Spite, M., Hellmann, J., Tang, Y., Mathis, S.P., Kosuri, M., Bhatnagar, A., Jala, V.R. and Haribabu, B. (2011) Deficiency of the Leukotriene B4 Receptor, BLT-1, Protects against Systemic Insulin Resistance in Diet-induced Obesity. The Journal of Immunology, 187, 1942-1949. http://dx.doi.org/10.4049/jimmunol.1100196

[26] Alvheim, A.R., Malde, M.K., Osei-Hyiaman, D., Lin, Y.H., Pawlosky, R.L., Madsen, L., Kristiansen, K., Frøyland, L. and Hibbeln, J.R. (2012) Dietary Linoleic Acid Elevates Endocannabinoids 2-AG and Anandamide and Induces Obesity. Obesity, 10, 1984-1994. http://dx.doi.org/10.1038/oby.2012.38

[27] Alvheim A.R., Torstensen B.E., Lin Y.H., Lillefosse H.H., Lock E.J., Madsen L., Frøyland L., Hibbeln J.R. and Malde M.K. (2014) Dietary Linoleic Acid Elevates the Endocannabinoids 2-AG and Anandamide and Promotes Weight Gain in Mice Fed a Low Fat Diet. Lipids, 49, 59-69. http://dx.doi.org/10.1007/s11745-013-3842-y

[28] Alvheim, A.R., Torstensen, B.E., Lin, Y.H., Lillefosse, H.H., Lock, E.J., Madsen, L., Hibbeln, J.R. and Malde, M.K. (2013) Dietary Linoleic Acid Elevates Endogenous 2-Arachidonoylglycerol and Anandamide in Atlantic Salmon (Salmo salar L.) and Mice, and Induces Weight Gain and Inflammation in Mice. British Journal of Nutrition, 109, 1508-1517. http://dx.doi.org/10.1017/S0007114512003364

[29] The Look AHEAD Research Group, Wing, R.R., Bolin, P., Brancati, F.L., Bray, G.A., Clark, J.M., Coday, M., Crow, R.S., Curtis, J.M., Egan, C.M., Espeland, M.A., Evans, M., Foreyt, J.P., Ghazarian, S., Gregg, E.W., Harrison, B., Hazuda, H.P., Hill, J.O., Horton, E.S., Hubbard, V.S., Jakicic, J.M., Jeffery, R.W., Johnson, K.C., Kahn, S.E., Kitabchi, A.E., Knowler, W.C., Lewis, C.E., Maschak-Carey, B.J., Montez, M.G., Murillo, A., Nathan, D.M., Patricio, J., Peters, A., Pi-Sunyer, X., Pownall, H., Reboussin, D., Regensteiner, J.G., Rickman, A.D., Ryan, D.H., Safford, M., Wadden, T.A., Wagenknecht, L.E., West, D.S., Williamson, D.F. and Yanovski, S.Z. (2013) Cardiovascular Effects of Intensive Lifestyle Intervention in Type 2 Diabetes. The New England Journal of Medicine, 369, 145-154. http://dx.doi.org/10.1056/NEJMoa1212914

[30] Lands, W.E.M. (2003) Diets Could Prevent Many Diseases. Lipids, 38, 317-321. http://dx.doi.org/10.1007/s11745-003-1066-0

[31] Marugame, T. and Mizuno, S. (2005) Comparison of Prostate Cancer Mortality in Five Countries: France, Italy, Japan, UK and USA from the WHO Mortality Database (1960-2000). Japanese Journal of Clinical Oncology, 35, 690-691. http://dx.doi.org/10.1093/jico/hyi185

[32] Howlader, N., Noone, A.M., Krapcho, M., Garshell, J., Miller, D., Altekruse, S.F., Kosary, C.L., Yu, M., Ruhl, J., Tatalovich, Z., Mariotto, A., Lewis, D.R., Chen, H.S., Feuer, E.J. and Cronin, K.A., Eds. (2015) Prostate Cancer: Cancer Statistics Review, 1975-2012, National Cancer Institute. http://seer.cancer.gov/statfacts/html/prost.html

[33] Huang, R.Y., Li, S.S., Guo, H.Z., Huang, Y., Zhang, X., Li, M.Y., Chen, G.G. and Zeng, X. (2014) Thromboxane A2 Exerts Promoting Effects on Cell Proliferation Through Mediating Cyclooxygenase-2 Signal in Lung Adenocarcinoma Cells. Journal of Cancer Research and Clinical Oncology, 140, 375-386. http://dx.doi.org/10.1007/s00432-013-1573-3

[34] Ramsden, C.E., Faurot, K.R., Zamora, D., Suchindran, C.M., MacIntosh, B.A., Gaylord, S., Ringel, A., Hibbeln, J.R., Feldstein, A.E., Mori, T.A., Barden, A., Lynch, C., Coble, R., Mas, E., Palsson, O., Barrow, D.A. and Mann, J.D. (2013) Targeted Alteration of Dietary n-3 and n-6 Fatty Acids for the Treatment of Chronic Headaches: A Randomized Trial. Pain, 154, 2441-2451. http://dx.doi.org/10.1016/j.pain.2013.07.028

[35] EFAeducation.org (2015) Omega 3-6 Apps Use Balance Scores. http://efaeducation.org/omega-3-6-apps/

[36] Bibus, D. and Lands, B. (2015) Balancing Proportions of Competing Omega-3 and Omega-6 Highly Unsaturated Fatty Acids (HUFA) in Tissue Lipids. Prostaglandins LeukotEssent Fatty Acids, 99, 19-23.

http://www.plefa.com/article/S0952-3278(15)00087-3/pdf http://dx.doi.org/10.1016/j.plefa.2015.04.005 
[37] Ramsden, C.E., Faurot, K.R., Zamora, D., Palsson, O.S., MacIntosh, B.A., Gaylord, S., Taha, A.Y., Rapoport, S.I., Hibbeln, J.R., Davis, J.M. and Mann, J,D. (2015) Targeted Alterations in Dietary n-3 and n-6 Fatty Acids Improve Life Functioning and Reduce Psychological Distress among Patients with Chronic Headache: A Secondary Analysis of a Randomized Trial. Pain, 156, 587-596. http://dx.doi.org/10.1097/01.j.pain.0000460348.84965.47

[38] MacIntosh, B.A., Ramsden, C.E., Faurot, K.R., Zamora, D., Mangan, M., Hibbeln, J.R. and Mann, J.D. (2013) Low-n-6 and Low-n-6 Plus High-n-3 Diets for Use in Clinical Research. British Journal of Nutrition, 110, 559-568. http://dx.doi.org/10.1017/S0007114512005181

[39] Wood, K.E., Mantzioris, E., Gibson, R.A. and Muhlhausler, B.S. (2013) Incorporating Macadamia Oil and Butter to Reduce Dietary Omega-6 Polyunsaturated Fatty Acid Intake. Nutrition \& Dietetics, 70, 94-100. http://dx.doi.org/10.1111/j.1747-0080.2012.01636.x

[40] U.S. Department of Defense (2013) Defense Science Board Study on Technology Innovation Enablers for Superiority in 2030. 80-83. http://www.acq.osd.mil/dsb/reports/DSB2030.pdf

[41] Marriott, B.P., Yu, K., Majchrzak-Hong, S., Johnson, J. and Hibbeln, J.R. (2014) Understanding Diet and Modeling Changes in the Omega-3 and Omega-6 Fatty Acid Composition of U.S. Garrison Foods for Active Duty Personnel. Military Medicine, 179, 168-175. http://dx.doi.org/10.7205/MILMED-D-14-00199

[42] Lin, Y.H., Hanson, J.A., Strandjord, S.E., Salem, N.M., Dretsch, M.N., Haub, M.D. and Hibbeln, J.R. (2014) Fast Transmethylation of Total Lipids in Dried Blood by Microwave Irradiation and Its Application to a Population Study. Lipids, 49, 839-851. http://dx.doi.org/10.1007/s11745-014-3918-3

[43] DuPont Pioneer (2015) Plenish ${ }^{\circledR}$ High Oleic Soybeans https://www.pioneer.com/home/site/us/products/soybean/enhanced-oil-soybeans/

[44] Branch, W.D. (2014) Registration of “Georgia-13M” Peanut. Journal of Plant Registrations, 8, 253-256. http://dx.doi.org/10.3198/jpr2013.11.0071crc

[45] Gorbet, D. (2003) SunOleic ${ }^{\circledR / H i g h ~ O l e i c ~ P e a n u t s: ~ A ~ S t e p ~ F o r w a r d . ~}$ http://ufdcimages.uflib.ufl.edu/IR/00/00/15/85/00001/AG15900.pdf

[46] Isleib, T.G., Pattee, H.E., Sanders, T.H., Hendrix, K.W. and Dean, L.O. (2006) Compositional and Sensory Comparisons between Normal- and High-Oleic Peanuts. Journal of Agricultural and Food Chemistry, 54, 1759-1763. http://dx.doi.org/10.1021/jf052353t

[47] Derbyshire, E.J. (2014) A Review of the Nutritional Composition, Organoleptic Characteristics and Biological Effects of the High Oleic Peanut. International Journal of Food Sciences and Nutrition, 65, 781-790. http://dx.doi.org/10.3109/09637486.2014.937799

[48] Haytowitz, D.B. (2012) List of Key Foods Based on NHANES 2007-08. http://www.ars.usda.gov/SP2UserFiles/Place/12354500/Data/KeyFoods/Keyfoods 0708.xlsx 